\title{
KADAR PRO-INFLAMATOR SITOKIN INTERLEUKIN (IL) - 18 PADA REMAJA OBESITAS DENGAN SINDROM METABOLIK
}

\author{
Regina Anggraini Rodriques, Muhammad Sulchan ${ }^{*}$ \\ Program Studi Ilmu Gizi Fakultas Kedokteran Universitas Diponegoro \\ J1.Dr.Sutomo No.18, Semarang, Telp (024) 8453708, Email : gizifk@ undip.ac.id
}

\begin{abstract}
Background: Metabolic syndrome (MetS) began with the incidence of obesity in adolescent specifically central obesity, which will increase the risk of cardiovascular disease when adolescent became adult. Comorbidity factor in state of obesity accompanied by MetS was the increasing of pro-inflammatory cytokine interleukin (IL) - 18. The study of IL-18 in obese adolescents with MetS had not been done in Indonesia. The purpose of the study is to define IL-18 levels, describe correlations risk factors of MetS with IL-18 level in obese adolescent.

Method: A cross-sectional study was conducted in Senior High 2 Semarang. Pre-MetS is defined from 1 or 2 following risk factors, MetS is defined $\geq 3$ following risk factors: waist circumference and blood pressure $\geq$ the $90^{\text {th }}$ percentile, $H D L \leq 40 \mathrm{mg} / \mathrm{dL}$, triglycerides $\geq 110 \mathrm{mg} / \mathrm{dL}$, dan fasting glucose blood level $\geq 100 \mathrm{mg} / \mathrm{dL}$. The differences of level IL-18 between Pre-MetS group and MetS group were described by independent t-test, and correlations between the risk factors of MetS with IL-18 levels were described by Spearman test.

Result: 47 adolescents subjects with age of 15 -17 years, 37 subjects with Pre-MetS and 10 subjects with MetS. Average levels of IL-18 in obese adolescents with MetS were $482.40 \mathrm{pg} / \mathrm{mL}$, while average levels of IL-18 in obese adolescents with Pre-MetS were $358.41 \mathrm{pg} / \mathrm{mL}(p=0.048)$. Risk factors of MetS: blood pressure systolic and diastolic $(p=0.001$ dan $p=0.003)$, waist circumference $(p=0.048)$, and HDL $(p=0.006)$ had correlation with IL-18 levels.

Conclusion: Levels of IL-18 in obese adolescents with MetS were significantly higher than in obese adolescents with Pre-MetS. Three from five risk factors of Mets which blood pressure, waist circumference, and HDL had significant correlation with IL-18 levels in obese adolescents.
\end{abstract}

Keyword : obese adolescent, central obesity, metabolic syndrome, IL-18

\section{ABSTRAK}

Latar Belakang: Sindrom metabolik (SM) diawali dengan kejadian obesitas pada remaja, terutama obesitas sentral, akan meningkatkan risiko kejadian penyakit kardiovaskular ketika remaja menjadi dewasa. Faktor komorbiditas keadaan obesitas yang diikuti sindrom metabolik adalah adanya peningkatan proinflamator sitokin yaitu interleukin (IL) - 18. Penelitian mengenai IL-18 pada remaja obesitas dengan SM belum pernah dilakukan di Indonesia. Tujuan dari studi ini adalah untuk menentukan kadar IL-18, dan melihat hubungan faktor risiko SM dengan kadar IL-18 pada remaja obesitas.

Metode: Jenis penelitian cross sectional yang dilakukan di SMA Negeri 2 Semarang. Keadaan Pra SM ditentukan dari 1 atau 2 faktor risiko sedangkan SM ditentukan dari $\geq 3$ faktor risiko: lingkar pinggang dan tekanan darah $\geq$ persentil ke-90, HDL $\leq 40 \mathrm{mg} / \mathrm{dL}$, trigliserida $\geq 110 \mathrm{mg} / \mathrm{dL}$, dan glukosa darah puasa $\geq 100 \mathrm{mg} / \mathrm{dL}$. Perbedaan kadar IL-18 antara kelompok Pra SM dan kelompok SM menggunakan independent t-test, dan hubungan antara faktor risiko SM dengan kadar IL-18 dideskripsikan dengan uji Spearman.

Hasil: 47 subjek remaja usia 15 -17 tahun, 37 subjek Pra SM dan 10 subjek SM. Rerata kadar IL - 18 pada remaja obesitas dengan SM sebesar 482.40 pg/mL, sedangkan rerata kadar IL-18 pada remaja obesitas dengan Pra SM sebesar $358.41 \mathrm{pg} / \mathrm{mL}(p=0.048)$. Faktor risiko SM: tekanan darah sistolik dan diastolik $(p=0.001$ dan $p=0.003)$, lingkar pinggang $(p=0.048)$, dan HDL $(p=0.006)$ memiliki korelasi dengan kadar IL-18.

Simpulan: Kadar IL- 18 pada remaja obesitas dengan SM lebih tinggi secara bermakna dibandingkan dengan Pra SM. Tiga dari lima faktor risiko SM yaitu tekanan darah, lingkar pinggang, dan HDL memiliki korelasi yang bermakna dengan kadar IL-18 pada remaja obesitas.

Kata kunci: remaja obesitas, obesitas sentral, sindrom metabolik, IL-18

\section{PENDAHULUAN}

Obesitas dan sindrom metabolik (SM) telah menjadi masalah besar tidak hanya di negara maju namun di negara berkembang seperti Indonesia. ${ }^{1}$ Sindrom metabolik yang merupakan kumpulan dari berbagai macam gejala yang mempengaruhi proses biokimiawi tubuh sehingga tidak bekerja dengan normal. Keadaan ini pada umumnya diawali dengan obesitas, terutama obesitas sentral. ${ }^{2,3}$ Kejadian sindrom metabolik akan meningkat seiring dengan meningkatnya kejadian obesitas. Seperti suatu studi yang

\footnotetext{
${ }^{*}$ Penulis Penanggungjawab
} 
dilakukan di Bali pada tahun 2011 menunjukkan bahwa prevalensi sindrom metabolik didapatkan sebesar $18.2 \%$ dan obesitas sentral didapatkan sebesar $35 \%{ }^{4}$

Risiko terjadinya sindrom metabolik yang diawali dengan kejadian obesitas menjadi suatu kekhawatiran tersendiri di negara Indonesia. Kejadian obesitas yang dialami oleh warga Indonesia sudah dimulai sejak dini, bahkan dari usia remaja. Seperti hasil yang ditunjukkan oleh Riset Kesehatan Dasar (Riskesdas) bahwa terjadi peningkatan prevalensi obesitas sentral remaja usia $\geq 15$ tahun pada tahun 2013 dibandingkan pada tahun 2007. Prevalensi obesitas sentral remaja tahun 2013 sebesar 26.6\% lebih tinggi dari tahun 2007 sebesar 18.8\%.5 Peningkatan prevalensi obesitas pada remaja perlu diperhatikan lebih seksama, karena obesitas yang dialami pada usia remaja akan meningkatkan risiko lebih besar terjadinya sindrom metabolik ketika dewasa. ${ }^{6,7,8}$ Kejadian obesitas terutama obesitas sentral yang dialami remaja juga mampu meningkatkan risiko terjadinya sindrom metabolik yang diikuti dengan berbagai penyakit seperti penyakit kardiovaskular, diabetes mellitus tipe 2 (DM II), dan penyakit kronis lainnya., ${ }^{9,10}$

Berbagai macam faktor dapat menjadi penyebab timbulnya obesitas pada remaja. Faktorfaktor yang signifikan dalam mempengaruhi kejadian obesitas adalah kelebihan asupan dan physical inactivity, yang nantinya akan memberikan andil dalam perkembangan sindrom metabolik. ${ }^{11,12}$ Terjadi penyimpangan asupan makan dalam konteks kelebihan asupan, pola makan yang salah dari jenis sumber asupan yang sering dikonsumsi remaja saat ini. Bila dilihat dari perkembangan jenis makanan yang dikonsumsi masyarakat Indonesia saat ini sudah terjadi keadaan yang tidak sesuai dengan harapan. Jenis makanan yang tersedia di pasaran cenderung merupakan unhealthy food yang tinggi kalori, tinggi lemak, tinggi garam, tinggi karbohidrat simplex, dan rendah serat. Jenis asupan makanan inilah yang kemungkinan menjadi penyebab utama meningkatnya prevalensi obesitas maupun obesitas sentral pada remaja.

Keadaan obesitas sentral pada remaja kemudian ditentukan melalui pengukuran lingkar pinggang. ${ }^{13}$ Batas standar lingkar pinggang terjadinya obesitas sentral khususnya pada remaja Indonesia yang masuk dalam etnis South-Asian adalah laki-laki dan perempuan $\geq$ persentil ke $90 .{ }^{13}$ Terdapat 5 faktor risiko untuk mendiagnosa SM, yaitu obesitas sentral dengan pengukuran lingkar pinggang, peningkatan kadar trigliserida, penurunan kadar kolesterol HDL (High Density Lipoprotein), peningkatan tekanan darah, dan resistensi insulin yang dilihat dengan adanya peningkatan kadar glukosa darah puasa. ${ }^{13,14}$ Melalui 5 faktor risiko sindrom metabolik tersebut, maka sindrom metabolik dapat dibedakan menjadi 2 kelompok, yaitu kelompok Pra-SM dengan 1 atau 2 faktor risiko, dan kelompok SM dengan $\geq 3$ faktor risiko.

Pendekatan yang dilakukan dari berbagai penelitian untuk mengetahui faktor komorbiditas yang menyertai keadaan sindrom metabolik adalah faktor peningkatan agen pro-inflamator. Peningkatan agen pro-inflamator yang banyak terlihat seperti peningkatan kadar C-reactive protein (CRP), tumor necrosis factor $-\alpha(\mathrm{TNF}-\alpha)$, interferon-gamma (IFN- $\gamma$ ), interleukin (IL) -6 , dan yang paling baru adalah IL-18. ${ }^{15}$ Peningkatan kadar IL-18 merupakan biomarker baru yang ditemukan bersamaan dengan kejadian sindrom metabolik. ${ }^{15}$

IL-18 merupakan salah satu anggota keluarga sitokin IL-1, yang meningkat pada keadaan sindrom metabolik yang diawali dengan obesitas. ${ }^{16}$ Beberapa studi menyebutkan bahwa IL18 yang bertindak sebagai mediator inflamasi lokal berpotensi sebagai prediktor penyakit kardiovaskular, karena mekanisme IL-18 yang dapat menginduksi IFN- $\gamma$. IFN- $\gamma$ dikeluarkan sebagai respon imun untuk menunjukkan kejadian lesi aterosklerosis, serta menunjukkan adanya pembentukan plak-plak dalam pembuluh darah. ${ }^{17}$ Peranan IL-18 yang menunjukkan adanya plak pada pembuluh darah dari mekanisme penginduksian IFN- $\gamma$, membuat IL-18 menjadi mediator inflamasi yang penting. Obesitas merupakan hasil dari adanya inflamasi kronis di dalam tubuh yang mungkin menjadi penyebab peningkatan kadar IL-18 di dalam tubuh. ${ }^{18}$ Kelebihan asupan dan physical inactivity yang menyebabkan obesitas timbul ekspresi berbagai mediator-mediator pro-inflamasi terutama IL-18 yang diduga meningkat kadarnya bila diikuti dengan kejadian sindrom metabolik.

Hal tersebut mendorong peneliti untuk ditelitinya apakah remaja obesitas sudah memiliki faktor risiko sindrom metabolik, apakah sudah terdapat peningkatan kadar IL-18 pada remaja obesitas dengan sindrom metabolik dengan melihat perbedaan kadar IL-18 antara kelompok Pra-SM dan kelompok SM, serta menentukan faktor risiko sindrom metabolik apa yang berhubungan dengan kadar IL-18. 


\section{METODE}

Penelitian ini merupakan penelitian observasional dengan rancangan penelitian cross sectional. ${ }^{19}$ Variabel terikat (dependent) dalam penelitan ini adalah kadar IL-18. Variabel bebas (independent) adalah faktor risiko sindrom metabolik yaitu lingkar pinggang, tekanan darah, glukosa darah puasa, trigliserida, dan HDL.

Subjek penelitian merupakan remaja siswa-siswi kelas $\mathrm{X}$ dan XI SMA Negeri 2 Semarang. Kriteria inklusi penelitian ini adalah remaja usia 15-18 tahun yang mengalami obesitas ditandai dengan IMT $\geq$ persentil ke-95 grafik persentil IMT. Subjek tersebut tidak dalam keadaan yang dapat meningkatkan kadar IL-18. ${ }^{20}$

Skrining dilakukan terhadap 835 subjek siswa-siswi yang ditentukan berdasarkan IMT. Berat badan diukur menggunakan timbangan berat badan dengan ketelitian $0.1 \mathrm{~kg}$, dan tinggi badan diukur menggunakan microtoise dengan ketelitian $0.1 \mathrm{~cm}$. Dari proses skrining didapatkan 61 orang siswa siswi yang memenuhi kriteria inklusi, namun yang bersedia menjadi subjek penelitian sebanyak 47 orang.

Subjek penelitian diukur lingkar pinggang (LP) untuk menentukan keadaan obesitas sentral, menggunakan pita ukur, dengan nilai LP laki-laki $\geq 93 \mathrm{~cm}$ dan perempuan $\geq 87 \mathrm{~cm}$. Darah puasa diambil oleh petugas laboratorium terakreditasi, untuk menentukan kadar trigliserida (TG), kadar HDL, dan kadar glukosa darah puasa (GDP). Analisis penentuan kadar TG menggunakan metode enzymatic (Beckamn TG Reagent), kadar HDL menggunakan magnesium-dextran sulfate precipitation reagent untuk memisahkan HDL yang diuji secara enzimatik, dan kadar GDP dilihat menggunakan metode enzymatic colorimetric (Sigma Chemical Company, St. Louis, MO, USA). Data tekanan darah (TD) diperiksa petugas dengan metode tidak langsung (Indirect Methode) dengan cara Auskultasi sebanyak 2 kali. Setelah didapatkan data hasil analisis LP, TG, HDL, GDP, dan TD, ke-47 subjek dibagi menjadi 2 kelompok yang terdiri dari kelompok Pra-SM dengan 1 atau 2 faktor risiko dan kelompok SM dengan $\geq 3$ faktor risiko. Penentuan kelompok ini berdasarkan faktor risiko sindrom metabolik yang dimiliki oleh subjek: obesitas sentral dengan LP pada laki-laki $\geq$ $93 \mathrm{~cm}$, dan pada perempuan $\geq 87 \mathrm{~cm}$, kadar $\mathrm{TG} \geq$ $110 \mathrm{mg} / \mathrm{dL}$, kadar HDL $\leq 40 \mathrm{mg} / \mathrm{dL}$, kadar GDP $\geq$ $100 \mathrm{mg} / \mathrm{dL}$, TD sistolik $\geq 122 \mathrm{mmHg}$, dan TD diastolik $\geq 77$ mmHg. ${ }^{14}$ Dari penentuan ini didapatkan 37 subjek pada kelompok Pra-SM dan 10 subjek pada kelompok SM.

pemeriksaan kadar IL-18 di Laboratorium

GAKI Fakultas Kedokteran Universitas Diponegoro Semarang, dengan metode enzymelinked immunosorbent assay (ELISA) menggunakan ELISA kit (Medical \& Biological Laboratories Co., LTD., Nagoya, Japan) dianalisis dengan Dynex MRX II microplate-reader (DYNEX Technologies, Inc. Chantilly, VA USA) yang dibaca pada panjang gelombang $450 \mathrm{~nm}^{22}$

Uji perbedaan kadar IL-18 pada kelompok Pra-SM dan kelompok SM menggunakan independent t-test. Perbedaan kadar IL-18 pada jumlah faktor risiko sindrom metabolik yang dimiliki subjek menggunakan uji ANOVA. Frekuensi kategori kadar IL-18 pada subjek menggunakan uji Fisher-exact karena komponen data kurang dari $50 \%$. Korelasi masing-masing faktor risiko sindrom metabolik dengan kadar IL18 menggunakan uji Spearman.

\section{HASIL PENELITIAN \\ Karakteristik Subjek}

Karakteristik subjek yang terdiri dari usia, jenis kelamin, status gizi, dan faktor risiko sindrom metabolik digunakan untuk mendeskripsikan subjek penelitian secara jelas dan sistematis. Hasil skrining remaja dari 835 siswa siswi SMA Negeri 2 Semarang menunjukkan 80 siswa (9.58\%) mengalami overweight, 66 siswa (7.9\%) mengalami obesitas, 61 siswa $(7.3 \%)$ mengalami obesitas sentral. Dari 61 siswa yang mengalami obesitas sentral, 47 diantaranya yang menjadi subjek penelitian. Karakteristik subjek penelitian disajikan dalam tabel 1.

Pada tabel 1, menunjukkan bahwa ke-47 subjek memiliki status gizi obesitas berdasarkan IMT $\geq$ persentil ke-95 (100\%), semua subjek juga mengalami obesitas sentral dengan nilai LP $\geq$ persentil ke-90 (100\%). Dari ke-47 subjek, 37 subjek (78.7\%) mengalami pra sindrom metabolik, diantaranya adalah 28 subjek laki-laki dan 19 subjek perempuan. Sepuluh subjek lainnya (21.3\%) mengalami sindrom metabolik yang dialami oleh subjek laki-laki saja. Frekuensi faktor risiko sindrom metabolik yang dimiliki masingmasing subjek pada kelompok Pra-SM dan kelompok SM dapat dilihat pada tabel 2. 
Tabel 1. Nilai Rerata dan Median pada Usia, Jenis Kelamin, Status Gizi, dan Faktor Risiko Sindrom Metabolik pada Subjek

\begin{tabular}{|c|c|c|}
\hline Variabel & Pra Sindrom Metabolik & Sindrom Metabolik \\
\hline Total & $(n=37)$ & $(\mathbf{n}=10)$ \\
\hline Usia & $16.00(15-17)^{\mathrm{b}}$ & $16.50(15-17)^{\mathrm{b}}$ \\
\hline $\operatorname{IMT}\left(\mathrm{Kg} / \mathrm{m}^{2}\right)$ & $30.34(26.0-43.3)^{\mathrm{b}}$ & $32.45(29.6-45.6)^{\mathrm{b}}$ \\
\hline $\mathrm{LP}(\mathrm{cm})$ & $93.5(87-134)^{b}$ & $105.98 \pm 8.00$ \\
\hline $\mathrm{HDL}(\mathrm{mg} / \mathrm{dL})$ & $42.81 \pm 6.51^{\mathrm{a}}$ & $32.50(30-48)^{\mathrm{b}}$ \\
\hline TDS (mmHg) & $110(100-140)^{\mathrm{b}}$ & $130 \pm 7.81^{\mathrm{a}}$ \\
\hline $\mathrm{TDD}(\mathrm{mmHg})$ & $70(70-80)^{\mathrm{b}}$ & $70(70-80)^{b}$ \\
\hline $\mathrm{TG}(\mathrm{mg} / \mathrm{dL})$ & $72(50-135)^{\mathrm{b}}$ & $117.20 \pm 32.49^{\mathrm{a}}$ \\
\hline GDP (mg/dL) & $82.24 \pm 6.18^{\mathrm{a}}$ & $79.90 \pm 10.97^{\mathrm{a}}$ \\
\hline Laki-laki & $(n=18)$ & $(n=10)$ \\
\hline Usia & $16(15-17)^{b}$ & $16.50(15-17)^{\mathrm{b}}$ \\
\hline $\operatorname{IMT}\left(\mathrm{Kg} / \mathrm{m}^{2}\right)$ & $31.65 \pm 4.52$ & $32.45(29.6-45.6)^{\mathrm{b}}$ \\
\hline $\mathrm{LP}(\mathrm{cm})^{(2) \mathrm{NS}}$ & $99.25(93-134)^{b}$ & $105.98 \pm 8.00^{\mathrm{a}}$ \\
\hline HDL (mg/dL) & $41.50 \pm 6.93$ & $32.50(30-48)^{\mathrm{b}}$ \\
\hline TDS (mmHg) & $120(110-140)^{b}$ & $130 \pm 7.81^{\mathrm{a}}$ \\
\hline TDD (mmHg) & $70(70-80)^{\mathrm{b}}$ & $70(70-80)^{\mathrm{b}}$ \\
\hline $\mathrm{TG}(\mathrm{mg} / \mathrm{dL})$ & $76.50 \pm 15.20^{\mathrm{a}}$ & $117.20 \pm 32.49^{\mathrm{a}}$ \\
\hline GDP (mg/dL) & $83.56 \pm 5.62^{\mathrm{a}}$ & $79.90 \pm 10.97^{\mathrm{a}}$ \\
\hline Perempuan & $(n=19)$ & \\
\hline Usia & $16(15-17)^{b}$ & - \\
\hline $\operatorname{IMT}\left(\mathrm{Kg} / \mathrm{m}^{2}\right)$ & $31.39 \pm 2.83^{\mathrm{a}}$ & - \\
\hline $\mathrm{LP}(\mathrm{cm})$ & $90(87-114)^{b}$ & - \\
\hline HDL (mg/dL) & $44.05 \pm 6.01^{\mathrm{a}}$ & - \\
\hline TDS (mmHg) & $110(100-120)^{b}$ & - \\
\hline $\mathrm{TDD}(\mathrm{mmHg})$ & 70 & - \\
\hline $\mathrm{TG}(\mathrm{mg} / \mathrm{dL})$ & $51(50-135)^{\mathrm{b}}$ & - \\
\hline GDP (mg/dL) & $81.00 \pm 6.57^{\mathrm{a}}$ & - \\
\hline
\end{tabular}

${ }^{\mathrm{a}}$ Rerata \pm sb, ${ }^{\mathrm{b}}$ Median, IMT Indeks Massa Tubuh, LP Lingkar Pinggang, TDS Tekanan Darah Sistolik, TDD Tekanan Darah Diastolik, GDP Gula Darah Puasa, $T G$ Trigliserida, $H D L$ High Density Lipoprotein.

Tabel 2. Frekuensi Faktor Risiko Sindrom Metabolik pada Subjek

\begin{tabular}{|c|c|c|c|c|}
\hline \multirow[t]{2}{*}{ Faktor Risiko } & \multicolumn{2}{|c|}{ Pra Sindrom Metabolik } & \multicolumn{2}{|c|}{ Sindrom Metabolik } \\
\hline & \multicolumn{2}{|c|}{$(n=37)$} & \multicolumn{2}{|c|}{$(n=10)$} \\
\hline LP (obesitas sentral) & 37 & $100 \%$ & 10 & $100 \%$ \\
\hline Trigliserida $\geq 110 \mathrm{mg} / \mathrm{dL}$ & 3 & $8.1 \%$ & 6 & $60 \%$ \\
\hline $\mathrm{HDL} \leq 40 \mathrm{mg} / \mathrm{dL}$ & 13 & $35.1 \%$ & 9 & $90 \%$ \\
\hline $\mathrm{GDP} \geq 100 \mathrm{mg} / \mathrm{dL}$ & - & - & 1 & $10 \%$ \\
\hline $\mathrm{TDS} \geq 122$ & 2 & $5.4 \%$ & 8 & $80 \%$ \\
\hline $\mathrm{TDD} \geq 77$ & 3 & $8.1 \%$ & 4 & $40 \%$ \\
\hline Laki-laki & \multicolumn{2}{|c|}{$(n=18)$} & \multicolumn{2}{|c|}{$(n=10)$} \\
\hline $\mathrm{LP} \geq 93$ & 18 & $100 \%$ & 10 & $100 \%$ \\
\hline Trigliserida $\geq 110 \mathrm{mg} / \mathrm{dL}$ & - & - & 6 & $60 \%$ \\
\hline $\mathrm{HDL} \leq 40 \mathrm{mg} / \mathrm{dL}$ & 9 & $50 \%$ & 9 & $90 \%$ \\
\hline $\mathrm{GDP} \geq 100 \mathrm{mg} / \mathrm{dL}$ & - & - & 1 & $10 \%$ \\
\hline $\mathrm{TDS} \geq 122$ & 2 & $11.1 \%$ & 8 & $80 \%$ \\
\hline $\mathrm{TDD} \geq 7$ & 3 & $16.7 \%$ & 4 & $40 \%$ \\
\hline Perempuan & \multicolumn{2}{|c|}{$(\mathbf{n}=19)$} & & \\
\hline $\mathrm{LP} \geq 87$ & 19 & $100 \%$ & - & - \\
\hline Trigliserida $\geq 110 \mathrm{mg} / \mathrm{dL}$ & 3 & $15.8 \%$ & - & - \\
\hline $\mathrm{HDL} \leq 40 \mathrm{mg} / \mathrm{dL}$ & 4 & $21.1 \%$ & - & - \\
\hline $\mathrm{GDP} \geq 100 \mathrm{mg} / \mathrm{dL}$ & - & - & - & - \\
\hline $\mathrm{TDS} \geq 122$ & - & - & - & - \\
\hline $\mathrm{TDD} \geq 77$ & - & - & - & - \\
\hline
\end{tabular}

IMT Indeks Massa Tubuh, LP Lingkar Pinggang, TDS Tekanan Darah Sistol, TDD Tekanan Darah Diastol, GDP Gula Darah Puasa, $T G$ Trigliserida, $H D L$ High Density Lipoprotein. 
Faktor Risiko Sindrom Metabolik dengan Kadar IL-18

Distribusi jumlah faktor risiko yang dimiliki subjek berdasarkan 5 faktor risiko sindrom metabolik yaitu LP, TD, kadar TG, kadar HDL, dan kadar GDP dapat dilihat pada gambar 1 dan tabel 3 .

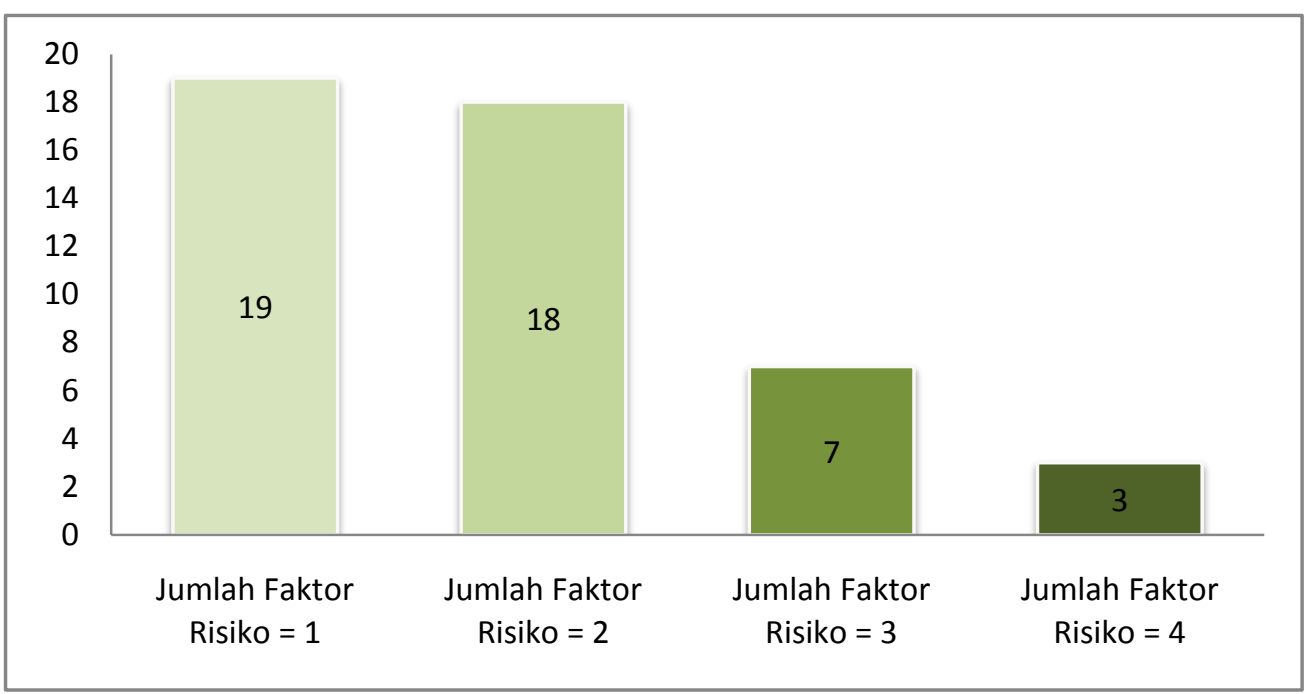

Gambar 1. Distribusi Jumlah Faktor Risiko Sindrom Metabolik yang dimiliki Subjek

Tabel 3. Rerata Kadar IL-18 pada Jumlah Faktor Risiko Sindrom Metabolik

\begin{tabular}{ccccc}
\hline $\begin{array}{c}\text { Jumlah Faktor Risiko } \\
\text { Sindrom Metabolik }\end{array}$ & $\mathbf{n}$ & $\mathbf{X}$ & Kadar Interleukin-18 & \multirow{2}{*}{$\boldsymbol{P}$} \\
\hline Jumlah Faktor Risiko $=1$ & 19 & 336.69 & 68.51 & \\
Jumlah Faktor Risiko $=2$ & 18 & 381.33 & 65.83 & 0.000 \\
Jumlah Faktor Risiko $=3$ & 7 & 399.62 & 110.51 & \\
Jumlah Faktor Risiko $=4$ & 3 & 657.55 & 112.51 & \\
\hline
\end{tabular}

Catatan: ${ }^{a}$ kadar dalam pikogram per millimeter

Pada tabel 3 menunjukkan data dalam ke-4 kelompok di atas menunjukkan varians data yang sama, sehingga uji yang dilakukan selanjutnya valid. Dari data diperoleh nilai $\mathrm{p}=0.000$ yang artinya "paling tidak terdapat perbedaan kadar IL18 yang bermakna pada dua kelompok." Data rerata kadar IL-18 pada kelompok Pra-SM dan kelompok SM dapat dilihat pada gambar 2. Pada gambar 2, ditunjukkan bahwa rerata kadar IL-18 pada kelompok Pra-SM adalah $358.41 \mathrm{pg} / \mathrm{mL}$, sedangkan pada kelompok SM adalah 483.4 pg/mL. Rerata kadar IL-18 pada kelompok Pra-SM lebih tinggi dibandingkan rerata kadar IL-18 pada kelompok Pra-SM.

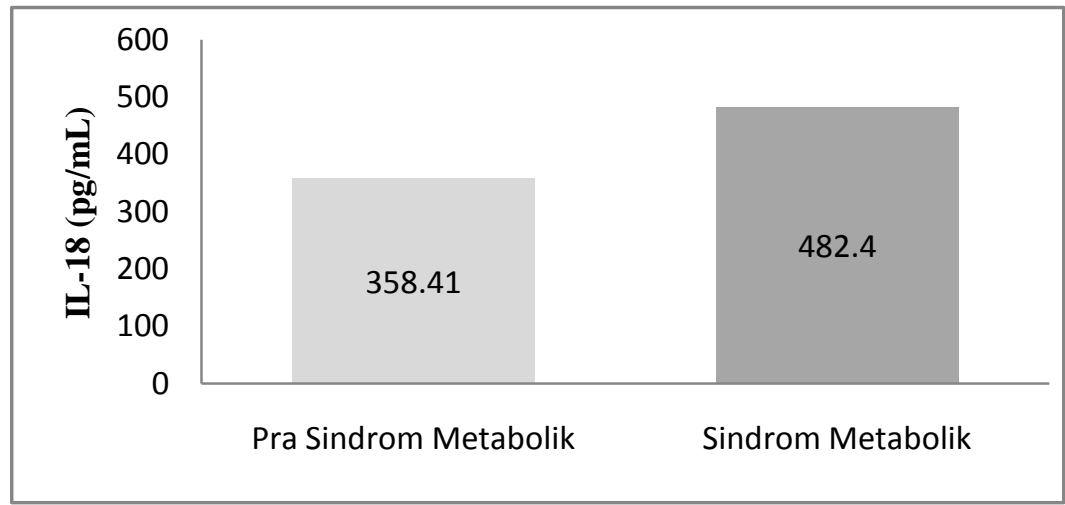

Gambar 2. Distribusi Rerata Kadar IL-18 pada Kelompok Pra Sindrom Metabolik dan Kelompok Sindrom Metabolik 
Data selanjutnya pada tabel 4 menunjukkan frekuensi jumlah subjek dari kedua kelompok yaitu kelompok Pra-SM dan kelompok SM yang memiliki kadar IL-18 pada kategori

normal dan tinggi. Pada data dalam tabel 4 hasil uji menunjukkan p>0.05 yang artinya bahwa "tidak ada perbedaan kategori kadar IL-18 antara kelompok Pra-SM dan kelompok SM."

Tabel 4. Frekuensi Jumlah Subjek pada Kategori Kadar IL-18

\begin{tabular}{|c|c|c|c|c|c|}
\hline Kategori Kadar IL-18 & \multicolumn{2}{|c|}{$\begin{array}{c}\begin{array}{c}\text { Pra Sindrom } \\
\text { Metabolik }\end{array} \\
(\mathbf{n}=37)\end{array}$} & \multicolumn{2}{|c|}{$\begin{array}{c}\begin{array}{c}\text { Sindrom } \\
\text { Metabolik }\end{array} \\
(\mathbf{n}=\mathbf{1 0}) \\
\end{array}$} & IL-18 $^{\mathrm{a}}$ \\
\hline Normal & 2 & $5.4 \%$ & 1 & $10 \%$ & $232.46 \pm 38.87^{\mathrm{b}}$ \\
\hline Tinggi & 35 & $94.6 \%$ & 9 & $90 \%$ & $382.81(258.21-798.80)^{\mathrm{c}}$ \\
\hline \multicolumn{6}{|l|}{ Laki-laki $^{(2)(\mathrm{NS})}$} \\
\hline Normal & - & - & 1 & $10 \%$ & \\
\hline Tinggi & 18 & $100 \%$ & 9 & $90 \%$ & $427.91 \pm 117.99^{\mathrm{b}}$ \\
\hline \multicolumn{6}{|l|}{ Perempuan } \\
\hline Normal & 2 & $10.5 \%$ & - & - & $254.90 \pm 1.55^{\mathrm{b}}$ \\
\hline Tinggi & 17 & $89.5 \%$ & - & - & $343.18 \pm 51.14^{\mathrm{b}}$ \\
\hline
\end{tabular}

$* \mathrm{p}<0.05, * *<0.01, \mathrm{NS}=$ Not Significant

${ }^{\mathrm{a}}$ kadar dalam $\mathrm{pg} / \mathrm{mL},{ }^{\mathrm{b}}$ Rerata $\pm \mathrm{sb},{ }^{\mathrm{c}}$ Range

\section{Perbedaan Kadar IL-18 antara Kelompok Pra Sindrom Metabolik dan Kelompok Sindrom Metabolik}

Tabel 5. Hasil Uji Perbedaan Kadar IL-18 antara Kelompok Pra Sindrom Metabolik dan Sindrom Metabolik

\begin{tabular}{cccccc}
\hline IL-18 & $\begin{array}{c}\text { Kategori Sindrom } \\
\text { Metabolik }\end{array}$ & $\mathbf{n}$ & $\begin{array}{c}\text { Median (minimum- } \\
\text { maksimum) }\end{array}$ & Mean \pm SD & $P^{*}$ \\
\hline & Pra Sindrom Metabolik & 37 & $365.04(253.80-521.50)$ & $358.41 \pm 70.03$ & 0.048 \\
\hline $\mathrm{p}<\mathrm{Sindrom} \mathrm{Metabolik}$ & 10 & $452.74(187.59-789.80)$ & $482.40 \pm 169.46$ & \\
\hline & & & & &
\end{tabular}

Hasil pada tabel 5 menunjukkan uji perbedaan rerata kadar IL-18 antara kelompok PraSM dan kelompok SM. Kedua data berdistribusi normal dengan $\mathrm{p}=0.048$ yang artinya bahwa "terdapat perbedaan bermakna rerata kadar IL-18 antara kelompok Pra-SM dan kelompok SM.” Pada penentuan perbedaan rerata diatas (tabel 5) ditemukan 1 subjek pada kelompok SM yang memiliki kadar Il-18 sangat tinggi yaitu 798.80 $\mathrm{pg} / \mathrm{mL}$. Subjek tersebut mengalami obesitas sentral, hipertensi, hipertrigliseridemia, dan kadar HDL yang rendah (memiliki $\geq 3$ faktor risiko sindrom metabolik). Kadar IL-18 pada subjek ini mendekati angka 800 merupakan angka yang 2x lipat lebih tinggi bila dibandingkan pada rerata kadar IL-18 pada kelompok SM yaitu 482.5 $\mathrm{pg} / \mathrm{mL}$, dan 4x lipat dibandingkan pada kadar normal.

\section{Korelasi antara Faktor Risiko Sindrom Metabolik dengan Kadar IL-18}

Tabel 6 menunjukkan korelasi antara faktor risiko sindrom metabolik dengan kadar IL18. Analisi dari data tersebut yaitu faktor risiko sindrom metabolik: tekanan darah sistolik dan diastolik ( $\mathrm{p}=0.001$ dan $\mathrm{p}=0.003)$, lingkar pinggang (0.048), dan kadar HDL $(\mathrm{p}=0.006)$ memiliki korelasi yang bermakna dengan kadar IL-18. Sedangkan faktor risiko TG $(\mathrm{p}>0.05)$ dan GDP ( $>0.05$ ) tidak memiliki korelasi yang bermakna dengan kadar IL-18.

Tabel 6. Korelasi Faktor Risiko Sindrom Metabolik dengan Kadar IL-18

\begin{tabular}{lccc}
\hline \multicolumn{1}{c}{$\begin{array}{c}\text { Faktor Risiko Sindrom } \\
\text { Metabolik }\end{array}$} & n & Interleukin-18 & R \\
\hline LP $(\mathrm{cm})$ & 47 & +0.290 & 0.048 \\
TDS (mmHg) & 47 & +0.467 & 0.001 \\
TDD (mmHg) & 47 & +0.426 & 0.003 \\
GDP (mg/dL) & 47 & +0.063 & 0.673 \\
TG (mg/dL) & 47 & +0.233 & 0.115 \\
HDL (mg/dL) & 47 & -0.394 & 0.006 \\
\hline
\end{tabular}

LP Lingkar Pinggang, TDS Tekanan Darah Sistol, TDD Tekanan Darah Diastol, GDP Gula Darah Puasa, TG Trigliserida, HDL High Density Lipoprotein. 


\section{PEMBAHASAN}

Hasil penelitian sudah sesuai dengan hipotesis yaitu ada perbedaan kadar IL-18 antara kelompok Pra-SM dan kelompok SM pada remaja obesitas. Terdapat perbedaan kadar IL-18 yang bermakna pling tidak pada 2 kelompok dari 4 kelompok jumlah faktor risiko sindrom metabolik yang dimiliki subjek. Tiga dari lima faktor risiko sindrom metabolik yaitu tekanan darah (sistolik dan diastolik), lingkar pinggang, dan kadar HDL memiliki korelasi yang bermakna terhadap kadar IL-18.

Berdasarkan analisis hasil penelitian semua subjek penelitian memiliki kondisi obesitas sentral dengan $<3$ atau $\geq 3$ faktor risiko sindrom metabolik. Dapat dikatakan bahwa keadaan obesitas, terutama obesitas sentral mengawali kejadian sindrom metabolik. Resistensi insulin yang terjadi dalam kondisi obesitas sentral dianggap sebagai faktor utama dalam kejadian sindrom metabolik. Suatu studi menyebutkan bahwa asupan diet tinggi lemak menginduksi peningkatan adiposit viseral yang membentuk obesitas sentral, menyebabkan awal terjadinya resistensi insulin pada hati. ${ }^{23}$ Pada awalnya peningkatan lemak dalam diet yang diasup ditujukan untuk menyimpan cadangan lemak di lemak viseral dan subkutan, namun hati menjadi sensitif terhadap peningkatan jumlah lemak pada depot viseral. Adanya asupan lemak yang berlebihan ini diikuti dengan perubahan ekspresi enzim (spt. Lipase lipoprotein, hormon sensitif Lipase, peroxisome proliferator-actived receptor$\gamma)$, membuat peningkatan produksi asam lemak bebas (free fatty acids/FFA) dari vena portal ke hati dan jaringan lain. Jumlah FFA yang berlebihan kemudian merangsang pankreas untuk mensekresikan insulin dalam jumlah banyak, namun tidak cukup mengendalikan hiperglikemi yang ditandai dengan peningkatan kadar glukosa darah puasa. Insulin dalam jumlah banyak juga mempercepat sintesis trigliserida di hati dan jaringan adiposa, akibatnya terjadi peningkatan trigliserida load pada partikel HDL yang dibuat oleh lipase hepatik. Keadaan ini merangasang hidrolisis trigliserida yang membuat kondisi hipertrigliseridemia dan penurunan kadar HDL. Resistensi insulin juga menurunkan kemampuan vasodilatasi pembuluh darah dan meningkatkan resorbsi garam, yang membuat Angiotensin II menyebabkan vasokontriksi pembuluh darah dan peningkatan tekanan darah. ${ }^{24,25}$ Mekanisme resistensi insulin ini yang dipercaya dalam meningkatkan keabnormalan faktor risiko sindrom metabolik.

Pada penelitian ini yang masuk ke dalam kelompok SM hanya subjek laki-laki, sedangkan semua subjek perempuan masuk ke dalam kelompok Pra-SM. Pada suatu studi menyebutkan bahwa sebenarnya perempuan memiliki risiko lebih besar mengalami sindrom metabolik dibandingkan laki-laki karena aktivitas fisik perempuan biasanya lebih sedikit dibandingkan laki-laki. ${ }^{26}$ Namun data pada subjek penelitian yang dilakukan ini, menunjukkan bahwa kadar HDL rendah hanya dimiliki oleh 4 subjek perempuan (21\%) sedangkan pada laki-laki dimiliki oleh 18 subjek (64.3\%). Hasil ini menunjukkan bahwa kemungkinan tingkat aktivitas fisik pada subjek perempuan lebih tinggi dibandingkan pada laki-laki sehingga sindrom metabolik pada pada penelitian ini hanya dialami oleh subjek laki-laki.

Kadar IL-18 dipengaruhi oleh faktor risiko sindrom metabolik. Jika diiurutkan berdasarkan referensi NCEP ATP III, maka faktor risiko yang paling berpengaruh yaitu lingkar pinggang, kadar HDL, tekanan darah, kadar trigliserida, dan yang terakhir kadar glukosa darah puasa. ${ }^{14}$ Hasil penelitian ini sendiri menunjukkan hanya 3 dari 5 faktor risiko sindrom metabolik yang berhubungan dengan kadar IL-18 yaitu tekanan darah, lingkar pinggang, dan kadar HDL, sedangkan kadar trigliserida dan kadar glukosa darah puasa tidak memiliki hubungan.

Pada penelitian yang dilakukan pada ke-47 subjek menunjukkan bahwa 44 subjek diantaranya memiliki kadar IL-18 yang tinggi dan 3 subjek lainnya memiliki kadar yang normal. Kadar normal IL-18 sendiri adalah $36-257.8 \mathrm{pg} / \mathrm{mL}^{22} \mathrm{Ke}-44$ subjek yang tergabung dalam kelompok pra-SM dan SM dengan kadar IL-18 yang tinggi menunjukkan bahwa terdapat peningkatan kadar IL-18 dari kadar normal seharusnya. Kadar IL-18 yang tinggi dimiliki oleh subjek dalam keadaan obesitas yang disertai sindrom metabolik, sehingga bisa dikatakan bahwa keadaan obesitas dan sindrom metabolik memiliki peluang besar dalam peningkatan kadar IL-18 di dalam tubuh. Hal ini diperkuat dengan studi yang menyebutkan bahwa obesitas dan sindrom metabolik secara independen berhubungan langsung dengan peningkatan kadar stress oksidatif yang dihubungkan dengan peningkatan Low Density Lipoprotein (LDL) oksidatif dan kadar stress inflamator. ${ }^{27}$ Peningkatan kadar stress inflamator secara spesifik adalah peningkatan pro-inflamator sitokin 
termasuk di dalamnya yaitu TNF- $\alpha$, CRP, IL-6, dan IL-18, yang merupakan biomarker inflamasi serta determinan yang kuat dalam menunjukkan kejadian aterosklerosis di masa depan. ${ }^{27}$

Mekanisme keadaan obesitas yang membuat terjadinya peningkatan kadar proinflamator, terutama IL-18 adalah akibat inflamasi kronis yang terjadi dalam keadaan tersebut. ${ }^{18}$ Keadaan obesitas disebut sebagai inflamasi dikarenakan penumpukkan jaringan lemak atau sel-sel adiposa yang mengisi rongga-rongga kosong di dalam tubuh terutama pada rongga di bagian abdominal sehingga disebut sebagai lemak viseral (lemak abdominal). Aktivitas terus menerus yaitu peningkatan produksi sel-sel adiposa inilah yang dianggap sebagai protein atau stimulus asing oleh mekanisme imun tubuh. Mekanisme imun tubuh mengidentifikasi sel-sel adiposa ini berbahaya dan mengancam tubuh, sehingga dikeluarkan respon imun oleh tubuh yaitu proses inflamasi yang memproduksi mediator-mediator pro-inflamasi seperti sitokin dan kemokin. Dalam proses inflamasi ini tubuh pada umumnya mengeluarkan agen toxic dan enzim proteolitik untuk mengeliminasi protein asing dan menetralisasi stimulus asing ini dari tubuh. Bila proses pengeliminasian dan netralisasi berhasil maka selanjutnya, mediator-mediator pro-inflamasi yang diproduksi tadi berapoptosis dan mengalami fagositosis oleh makrofag yang nantinya dibuang lewat drainase limfatik. Proses pengeliminasian dan netralisasi protein dan stimulus asing yang gagal membuat proses inflamasi tetap berlangsung dan produksi agen pro-inflamator terutama IL-18 terus meningkat, proses inilah yang disebut sebagai inflamasi kronis atau dikenal sebagai obesitas. ${ }^{28}$

Proses inflamasi kronis yang disebutkan di atas yang membuat produksi agen pro-inflamator terutama sitokin IL-18 meningkat dari kadar normalnya. Pernyataan ini diperkuat dari studi yang menyebutkan bahwa pola spesifik dari lowgrade immune pada remaja laki-laki dan perempuan dengan IMT dan lingkar pinggang yang tinggi atau resistensi insulin memiliki pola peningkatan agen pro-inflamator. ${ }^{29}$ Penelitian pada remaja obesitas sentral dengan sindrom metabolik ini, menunjukkan bahwa pro-inflamator sitokin IL18 lah yang mengalami produksi yang sangat tinggi sehingga terjadi peningkatan kadar IL-18 pada hampir semua subjek penelitian. Dari analisis kadar IL-18 pada subjek, terdapat 1 subjek pada kelompok SM dengan kadar IL-18 yang sangat tinggi yaitu $798.80 \mathrm{pg} / \mathrm{mL}$, hampir mencapai angka $800 \mathrm{pg} / \mathrm{mL}$. Referensi yang ada menunjukkan bahwa rerata kadar IL-18 sebesar 884 pg/mL ditemukan pada sampel penelitian dengan penyakit ginjal akut. ${ }^{30}$ Subjek penelitian ini sendiri tidak memiliki riwayat ginjal akut, sehingga perlu penelusuran lebih jauh apakah sudah terdapat komplikasi ginjal akibat manifestasi sindrom metabolik pada subjek.

Studi lain kemudian menyebutkan bahwa IL-18 merupakan prediktor kuat dalam menunjukkan penyakit kardiovaskular terutama aterosklerosis. Klaim ini perlu dipertegas dalam kisaran berapa kadar IL-18 ini menunjukkan keadaan kardiovaskular atau aterosklerosis. Contohnya dari penelitian yang dilakukan pada pasien penyakit Arteri Koroner (Coronary Artery Disease/CAD), menunjukkan bahwa pasien CAD dengan DM II memiliki kadar IL-18 dengan median $500.0(274.0$ - 684.0) $\mathrm{pg} / \mathrm{mL}$, dan pasien dengan CAD tanpa DM II dengan median 430.0 (262.0 - 688.0) pg/mL. ${ }^{31}$ Berdasarkan studi tersebut, maka rerata kadar IL-18 kelompok SM yang didapatkan dari penelitian sebesar 482.4 $\mathrm{pg} / \mathrm{mL}$, berada diantara rerata kadar IL-18 pada penyakit CAD. Hal ini menjadi kekhawatiran yang besar bahwa kemungkinan subjek penelitian pada kelompok SM memiliki risiko CAD yang lebih besar bila dibandingkan dengan pada kelompok Pra-SM atau bila dibandingkan pada kondisi normal tanpa sindrom metabolik. Studi lain juga menunjukan bahwa peningkatan kadar IL-18 diasosiasikan dengan adanya aterosklerosis yang telah dievaluasi melalui pemerikasaan ketebalan media intima dari arteri carotid dan pengukuran dari tingkat kekakuan arteri. ${ }^{32,33}$ Hasil studi yang ada diperkuat dengan hasil studi dari penelitian ini sendiri maka dapat dikatakan bahwa IL-18 berguna sebagai biomarker dalam terjadinya sindrom metabolik dan manajemen risiko penyakit-penyakit kardiovaskular. ${ }^{34}$

Kadar IL-18 yang sangat tinggi pada remaja obesitas sentral dengan sindrom metabolik juga mampu menjadi prediktor tingkat keparahan sindrom metabolik dan meningkatkan risiko terjadinya penyakit akibat sindrom metabolik seperti kardiovaskular, DM II, dan penyakit ginjal akut, atau penyakit kronis lain ketika remaja menjadi dewasa.

\section{SIMPULAN}

Rerata kadar pro-inflamator sitokin interleukin (IL) - 18 pada remaja obesitas dengan sindrom metabolik sebesar $482.40 \mathrm{pg} / \mathrm{mL}$, lebih tinggi dibandingkan rerata kadar IL-18 pada remaja obesitas dengan pra sindrom metabolik 
yaitu $358.41 \mathrm{pg} / \mathrm{mL}(\mathrm{p}=0.048)$. Terdapat korelasi yang bermakna antara faktor risiko sindrom metabolik: tekanan darah sistolik dan diastolik $(\mathrm{p}=0.001$ dan $\mathrm{p}=0.003)$, lingkar pinggang $(\mathrm{p}=0.048)$, dan kadar HDL $(\mathrm{p}=0.006)$ dengan kadar IL-18.

\section{SARAN}

Melanjutkan penelitian tentang uji kadar IL-18 dengan penambahan kelompok kontrol pada remaja yang tidak obesitas untuk melihat apakah terdapat perbedaan kadar IL-18.

\section{DAFTAR PUSTAKA}

1. Mangat C, Goel NK, Dinesh KW, Agarwal N, Sharma NK, Kaur J, et al. Metabolic Syndrome : A Challenging Health Issue in Highly Urbanized Union Territory of North India. BioMed Central: Diabetology and Metabolic Syndrome 2010;2:19.

2. Thaman RG dan Arora GP. Metabolic Syndrome: Definition and Pathophysiology-the discussion goes on. J Phys. \& Pharmaco. 2013;3(3):48-56.

3. Grundy SM. Metabolic Syndrome Pandemic. J AHA: Arteriosclerosis, Thrombosis, and Vasc Biol. 2008;28:629-636.

4. Dwipayana MP, Suastika K, Saraswati IMR, Gotera W, Budhiarta AAG, Sutanegara, et al. Prevalensi Sindroma Metabolik pada Populasi Penduduk Bali, Indonesia. Bag. Ilmu Penyakit Dalam FK Udayana Denpasar, Bali 2011.

5. Badan Penelitian dan Pengembangan Kesehatan Kementerian Kesehatan RI. Kecenderungan Prevalensi Obesitas Sentral Penduduk Umur $\geq 15$ tahun menurut Provinsi, Indonesia 2007 dan 2013. Riset Kesehatan Dasar (Riskesdas) 2013.

6. Sartika RAD. Faktor Risiko Obesitas pada Anak usia 5-15 tahun di Indonesia. FKM Universitas Indonesia. Makara Kesehatan 2011; 15:37-43.

7. Reilly JJ, Methven E, McDowell ZC, Hacking B, Alexander D, Stewart L, et al. British Medical J (BMJ): Health Consequences of Obesity 2003;88:748-752.

8. Engeland A, Bjorge T, Tverdal A, dan Sogaard AJ. Obesity in Adolescence and Adulthood and the Risk of Adult Mortality. Epidemiology 2004;15:1.

9. Batsis JA, Nieto-Martinez RE, dan Lopez-Jimenez F. Metabolic Syndrome: from Global Epidemiology to Individualize Medicine. Clic Phar \& Thera 2007;5:509-524.

10. Weiss R, Dziura J, Burgert TS, Tamborlane WV, Taksali SE, Yeckel CW, et al. Obesity \& the Metabolic Syndrome in Children \& Adolescents. J New Eng Med 2004;350::236-2374.

11. Misra A dan Shrivatava U. Obesity \& Dyslipidemia in South Asians. J Nutr 2013;5:2708-2733.
12. Bonomini F, Rodella LF, dan Rezzani R. Metabolic Syndrome, Aging, \& Involvement of Oxidative Stress. Aging \& Disease 2014;5:5.

13. The International Diabetes Federation (IDF) Consensus Worldwide Definition of Metabolic Syndrome. The New IDF definition of Metabolic Syndrome 2006.

14. Third Report of the National Cholesterol Education Program (NCEP) expert panel on detection, evaluation, \& treatment of high blood cholesterol in Adults (Adult Treatment Panel III). Final Report Circ 2002;106:3143-3421.

15. Troseid M, Seljeflot I, dan Arnesen H. The Role of Interleukin-18 in the Metabolic Syndrome. BioMed Central: Cardio Diabetology 2010;9:11.

16. Gracie JA, Robesrtseon RE, dan McInnes IB. Interleukin-18. J Leukoc Biol 2003;73:213-224.

17. Whitman SC, Ravisankar P, dan Daugherty A. Interleukin-18 Enhances Atherosclerosis in Apolipoprotein E Mice trough Release of Interferon- $\gamma$. Circ Res 2002;90:34-38.

18. Silviera LS, Monteiro PA, Antunes BMM, Seraphim PM, Fernandes RA, Destro SG, et al. Intra-abdominal Fat is Related to Metabolic Syndrome \& Non-Alcoholic Fat Liver Disease in Obese Youth. BioMed Central Pedia 2013;13:115.

19. Sastroasmoro S dan Ismael S. Dasar Metodologi Penelitian Klinis. Edisi ke-2. Jakarta: CV Agung Seto, 2002.

20. Dinarello CA, Daniela N, Soohyun K, dan Gilles K. IL-18 \& IL-18 Binding Protein. Frontiersin 2013;4:289.

21. Mexitalia M, Utari A, Sakundarno M, Yamauchi T, Subagio HW, dan Soemantri A. Sindroma Metabolik pada Remaja Obesitas. Media Medik Indo 2009;43(6):300-06.

22. MBL International Corporation. Human IL-18 ELISA Kit. Quantitative test kit for human IL-18 code No. 7620. BML Int Corp 2003.

23. Bergman RN, Kim SP, Catalano KJ, HSU IR, Chiu JD, Kabir M, et al. Why Fisceral Fat is BadL Mechanisms of the Metabolic Syndrome. Obesity 2006;14.

24. Miranda P, De FR, dan Califf R. Metabolic Syndrome: Definition, Pathophysiology, and Mechanism. J Am Heart. 2005;149:33-45.

25. Tripathy D, Mohanty $\mathrm{P}$, Dhindsa S, Syed T, Ghanim H, Aljada A, dan Dandona P. Elevation of Free Fatty Acids Induces Inflammation and Impair Vascular Reactivity in Healthy Subjects. Diabetes. 2003;52:2882-2887.

26. Ford ES, Giles WH, dan Dietz WH. Prevalence of the Metabolic Syndrome Among US Adults. JAMA 2002, Jan 16;287(3):356-359.

27. Van Guilder GP, Hoetzer GL, Greiner JJ, Satuffer BL, dan DeSouza CA. Influences of Metabolic Syndrome on Biomarkers of Oxidative Stress amd Inflammation in Obese Adults. Obesity 2006;14:2127-2131. 
28. Monteiro R dan Azevedo I. Chronic Inflammation in Obesity \& the Metabolic Syndrome. Hindawi Pub Corp Mediatord of Inflammation 2010.

29. Herder C, Schneitler S, Rathmann W, Haastert B, Schneitler $\mathrm{H}$, et al. Low-grade Inflammation, Obesity, \& Insulin Resistance in Adolescents. J Clin Endo \& Met 2007 ;92(12):4569-4574.

30. Sirota JC, Walcher A, Faubel S, Jani A, Mcfann K, Devarajan P, et al. Urine IL-18 are biomarkers of Acute Kidney Injury following Liver Transplantation. BMC Nephrol 2013;14:17.

31. Suchanek H, Mysliwska J, Siebert J, Wieckiewics J, Hak L, Szyndler K, dan Kartanowicz D. High Serm Interleukin-18 Concentrations in Patients with Coronary Artery Disease \& Type 2 Diabetes Mellitus. Eur Cytokine Netw 2005;16:177-185.

32. Yamagami H, Kitagawa K, Hoshi T, Furukado S, Hougaka H, Nagai Y, et al. Associations of Serum IL-18 levels with Carotid Intima-media Thickness. Arteri, Thro, \& Vas Biol 2005;25(7):1458-1462.

33. Troseid M, Sljeflot I, Weiss TW, Klemsdal TO, Hjerkinn EM, Arnesen H. Arterial Stiffness is Independently Associated with Interleukin-18 and Components of the Metabolik Syndrome. Artero 2006;(209):337-339.

34. Yamaoka-Tojo M, Tojo T, Wakaumen K, Kameda R, Nemoto S, Takahira N, et al. Circulating IL-18: A specific Biomarker for Atherosclerosis-prone Patient with Metabolic Syndrome. Nutr \& Metab 2011;8(3). 